Research papers

\title{
The penetrative mixing in the Laptev Sea coastal polynya pycnocline layer
}

\author{
Sergey A. Kirillov ${ }^{a, *}$, Igor A. Dmitrenko ${ }^{b}$, Jens A. Hölemann ${ }^{c}$, Heidemarie Kassens ${ }^{\text {d }}$, \\ Ekaterina Bloshkina ${ }^{a}$
}

${ }^{a}$ Arctic and Antarctic Research Institute, St. Petersburg, Russia

${ }^{\mathrm{b}}$ Centre for Earth Observation Science at the University of Manitoba, Winnipeg, Canada

${ }^{\mathrm{c}}$ Alfred Wegener Institute for Polar and Marine Research, Bremerhaven, Germany

${ }^{\mathrm{d}}$ Helmholtz Centre for Ocean Research, Kiel, Germany

\section{A R T I C L E I N F O}

\section{Article history:}

Received 18 October 2012

Received in revised form

25 April 2013

Accepted 29 April 2013

Available online 9 May 2013

\section{Keywords:}

Laptev Sea

Coastal polynya

Pycnocline

Penetrative mixing

\begin{abstract}
A B S T R A C T
The large recurrent areas of open water and/or thin ice (polynyas) producing cold brine-enriched waters off the fast-ice edge are evident in the Laptev Sea in winter time. A number of abrupt positively correlated transitions in temperature and salinity were recorded in the bottom and intermediate layers at a mooring station in the West New Siberian (WNS) polynya in February-March 2008. Being in the range of $\sim 0.5{ }^{\circ} \mathrm{C}$ and $\sim 1.6 \mathrm{psu}$ these changes are induced by horizontal motions across the polynya and correspond to temperature and salinity horizontal gradients in the range of $0.3-1.0{ }^{\circ} \mathrm{C} / 10 \mathrm{~km}$ and 1.4 $3.5 \mathrm{psu} / 10 \mathrm{~km}$, respectively. The events of distinct freshening and temperature decrease coincide with a northward current off the fast-ice edge, while southward currents brought saltier and warmer waters at intermediate depths. We suggest that the observed transitions are connected to altering pycnocline depths across the polynya. The source of relatively fresher waters at the intermediate depths in polynya is supposed to originate from penetrative mixing of surface low salinity waters to intermediate water depth. Several forcing processes that could be responsible for a penetrative mixing through the density interface in polynya are discussed. These are penetrative convection and shear-driven mixing that originates from two-layer water dynamics and/or baroclinic tidal motions. The heavily ridged seaward fast-ice edge could produce an additional source of turbulent mixing even through a shear-free density interface due to the increased roughness at the ice-water interface.
\end{abstract}

(c) 2013 Elsevier Ltd. All rights reserved.

\section{Introduction}

The offshore winds, blowing over the Siberian coast from November to May, create persistent areas of open water north of the land-fast ice that are known as the Great Siberian Polynya (Zakharov, 1966; Bareiss and Görgen, 2005; Martin and Cavalieri, 1989). Being exposed to the cold air temperature, these polynyas greatly affect the net ice production. The rate of ice production in the Laptev Sea polynyas during winter was reported to be within a wide range of $43-330 \mathrm{~km}^{3}$ (e.g. Zakharov, 1966; Martin and Cavalieri, 1989; Dethleff et al., 1998; Winsor and Bjork, 2000; Willmes et al., 2011). The combination of strong ice growth and continuous wind-driven removal of young ice from the polynya affects the local waters masses through brine release and a subsequent water salinification and cooling that both can lead to convective mixing (Aagaard et al., 1981; Martin and Cavalieri, 1989; Cavalieri and Martin, 1994). All these hydrographic responses are evident in the West New Siberian (WNS) coastal

\footnotetext{
* Corresponding author. Tel.: +7 8123523173.

E-mail address: skirillov@aari.ru (S.A. Kirillov).
}

polynya in the Laptev Sea (Zakharov, 1966; Dmitrenko et al., 2005, 2009).

The hydrography of the Laptev Sea shelf is also strongly affected by river discharge resulting in a pronounced density interface between saline marine waters and the relatively fresh river plume at the surface. During winter this density interface is supposed to prevent convective mixing of cold polynya waters down to the seafloor in the eastern Laptev Sea (Dmitrenko et al., 2005; Krumpen et al., 2011). On the other hand, the intermediate Atlantic waters (AW) may impact the hydrography of the Laptev Sea bringing warmer (and saltier) waters onto the outer shelf (Dmitrenko et al., 2001b). The wind-forced sporadic invasion of modified Atlantic waters from the north could result in positively correlated temperature and salinity changes in the bottom layer of the WNS polynya area (Dmitrenko et al., 2001a, 2010a). However, neither convective mixing in the polynya nor the inflow of modified AW can explain the newly available positively correlated time series of temperature and salinity observed in pycnocline layer of WNS polynya in FebruaryMarch 2008. Being measured in the vicinity of the fast-ice edge these records also demonstrate the sporadic freshening within pycnocline layer that contradict the generally accepted idea that colder and 
saltier water formed within polynya occupies the entire water column above the density interface.

The objective of this paper is to examine the response of the shelf hydrography to the processes in the polynya, in particular to the forcing mechanisms that explain the observed episodes of distinct freshening and temperature decrease (and vice versa) within the pycnocline at intermediate depths. The structure of the paper is as follows. The data used are summarized in Section 2. In Section 3 we present key features of the observed thermohaline changes and water dynamics within the WNS polynya. Subsequently the results are discussed in Section 4, while in Section 5 we draw the main conclusions.

\section{Material and methods}

In this study, we mainly use the data from a mooring (Anabar) which was deployed in the central Laptev Sea at the depth of $\sim 32 \mathrm{~m}$ during the Russian-German marine expedition TRANSDRIFT XII on R/ V Ivan Petrov in September 2007. This mooring was designed as an anchored taut line with subsurface flotation and acoustic release and consisted of two Acoustic Doppler Current Profilers (ADCP) from Teledyne-RDI and two Conductivity-Temperature-Depth (CTD) loggers equipped with turbidity sensors (XR-420 CTTu) by RBR Ltd.

The position of the mooring $\left(74^{\circ} 19.93^{\prime} \mathrm{N}, 128^{\circ} 0.03^{\prime} \mathrm{E}\right)$ at the seaward side of WNS polynya was approximately $35 \mathrm{~km}$ northwest from the fast-ice edge in January-May, 2008 (Fig. 1). A continuous 371-day time series of temperature, conductivity and current velocities were collected during deployment period from 2 September 2007 to 7 September 2008.

Temperature and conductivity were recorded every $30 \mathrm{~min}$ at $26.5 \mathrm{~m}$ (5.5 mab-meter above bottom) and $29 \mathrm{~m}$ (3.0 mab) with an estimated accuracy of $\pm 0.002{ }^{\circ} \mathrm{C}$ and $\pm 0.003 \mathrm{mS} / \mathrm{cm}$, respectively. For a typical range of measured conductivities, an accuracy

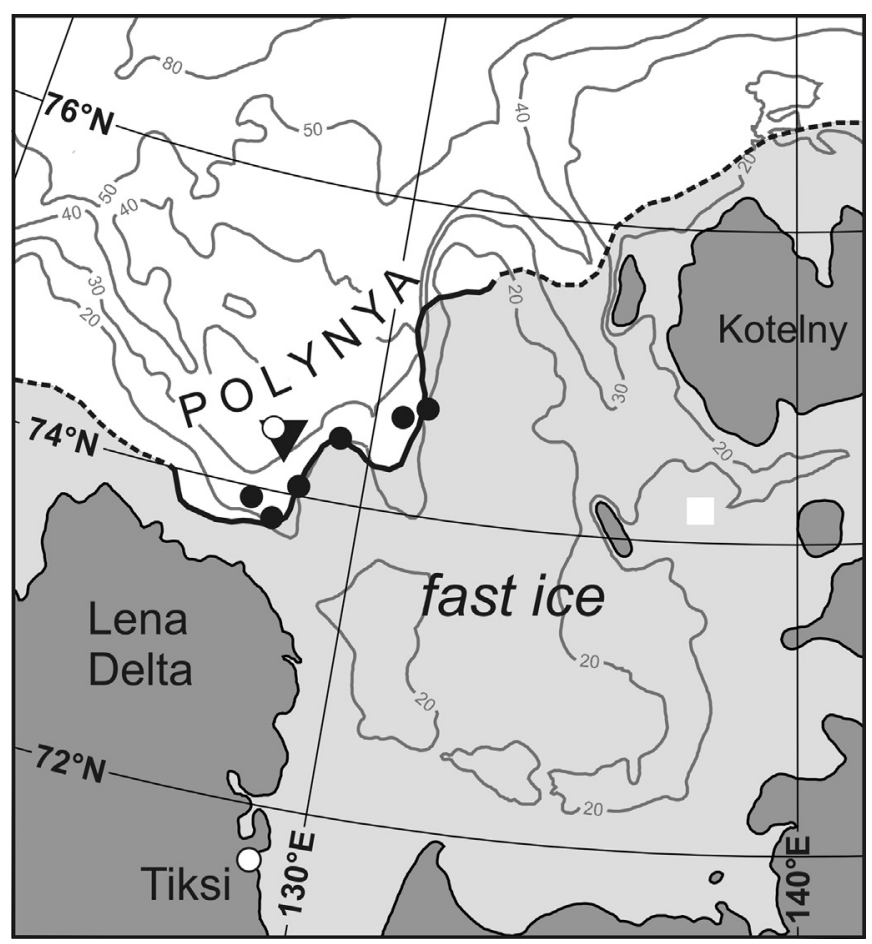

Fig. 1. The position of Anabar mooring and Transdrift XIII oceanographic station (triangle and circles respectively) relatively to the fast-ice edge in April 2008 (black line). Isobaths are shown with gray contours. of salinity can be declared as \pm 0.004 psu. Both CTD-loggers were calibrated before the cruise.

Both loggers were initially mounted beneath the layer of the seasonal pycnocline during summer that was identified during mooring deployment at about 14-19 m water depth (CTD profile taken with SeaBird 19plus). From June 2008, the conductivity data showed a pronounced drift (not shown) likely attributed to bio-fouling in summer time, which resulted in lowered salinities. At recovery in September 2008, the salinity difference between SeaBird 19plus cast and RBR at 5.5 and 3 mab were 1.38 and 2.42 psu respectively while the temperatures differed less than $0.01{ }^{\circ} \mathrm{C}$.

The CTD cast taken at the station Ti08-16 in 24 April (at pack ice $9 \mathrm{~km}$ north-west from Anabar mooring) during airborne TRANSDRIFT XIII winter expedition also revealed higher salinities at 5.5 and 3 mab in comparison with those measured by RBRs during the same period. The differences were 0.44 and $0.47 \mathrm{psu}$, respectively, while the temperatures at Ti08-16 were 0.04 and 0.06 colder than at the position of mooring Anabar. Well pronounced difference in temperatures suggests that measured discrepancies in salinity seem to be referred to the spatial changeability rather than to the bio-fouling.

The up-looking Workhorse Sentinel $300 \mathrm{kHz}$ ADCP installed at 3.2 mab samped velocity profile at $1-\mathrm{m}$ vertical bin size, with the first bin centered at about 7.5 mab. The down-looking Workhorse Sentinel $1200 \mathrm{kHz}$ ADCP was deployed at $5.3 \mathrm{mab}$ to sample current profile at 0.2 -m vertical bin size, with the first bin centered at about $4.6 \mathrm{mab}$. All profiles were averaged at $30 \mathrm{~min}$ intervals (70 and 110 pings per ensemble for $300 \mathrm{kHz}$ and $1200 \mathrm{kHz}$ ADCPs, respectively). Accuracies of current velocity measurements are $0.3 \%$ of reading $+0.3 \mathrm{~cm} / \mathrm{s}$ and $0.5 \%$ of reading $+0.5 \mathrm{~cm} / \mathrm{s}$ for Sentinel $1200 \mathrm{kHz}$ and $300 \mathrm{kHz}$ ADCPs, respectively. Directions are measured by both profilers with the same accuracy of $\pm 2^{\circ}$. After recovery all current data were corrected to account for the local magnetic deviation $\left(16^{\circ} \mathrm{E}\right)$. We also excluded the records from bins $\# 1-3$ (7.5-9.5 mab) in the record of the $300 \mathrm{kHz}$ ADCP and bins \#911 (2.6-3.0 mab) in the record of $1200 \mathrm{kHz}$ ADCP affected by acoustic shadow caused by other instruments or flotations.

Mooring-based observations were complemented by several CTD casts carried out during the Russian-German airborne expedition TRANSDRIFT XIII between 10 April and 5 May 2008. Positions of the stations are shown in Fig. 1. CTD data were collected by a pumped SBE 19plus with accuracies of $\pm 0.005{ }^{\circ} \mathrm{C}$ and \pm 0.001 psu for temperature and conductivity, respectively.

The openings of the WNS polynya near the Anabar mooring position were identified by using Envisat medium resolution $(1 \mathrm{~km})$ Synthetic Aperture Radar (SAR) data provided by the ESA together with AMSR-E passive microwave data provided by the NSIDC/NASA. The end of the polynya period was identified by SAR (no ice drift in the polynya area) in combination with AMSR-E data (no pixel with at least $50 \%$ ice concentration in the polynya area). Envisat images were also used to describe the position of the mooring relative to the fast-ice edge. Additionally, we use the data on wind speed measured at meteorological observatory in Tiksi to distinguish the wind pattern during polynya activity in February-April 2008.

The mean climatic summer (August-September) and winter (March-May) salinities in the area of research were taken from the historical oceanographic observations carried out in 1920-2009 (i. e. at the nodes of a regular $20 \times 20 \mathrm{~km}$ grid). For more details see Dmitrenko et al. (2009).

The MATLAB Tidal Analysis Toolbox by R. Pawlowicz, R. Beardsley and S. Lentz was used to separate the tidal signal in temperature, salinity and current records from the non-tidal components (Pawlowicz et al., 2002). This routine is the translation of a FORTRAN package developed by Foreman $(1977,1978)$.

The freezing temperature was calculated using a standard algorithm by Fofonoff and Millard (1983) with the input of in situ depth and salinity. 


\section{Results}

\subsection{Temperature and salinity records}

From September 2007 and until the end of January 2008, temperature and salinity measured at Anabar were negatively correlated at both 5.5 and 3.0 mab levels $(-0.86$ and -0.91 respectively). This fact is reasonably attributed to vertical mixing processes stirring warmer and less saline surface waters with relatively cold and saltier bottom waters (Hoelemann et al., 2011). The situation changed considerably in mid January and lasted until the end of April 2008 when temperature and salinity became positively correlated (+0.91 and +0.82 at 5.5 and 3.0 mab respectively). Fig. 2 shows the episodes when the remarkable positively correlated temperature $(T)$ and salinity $(S)$ changes were captured at the Anabar mooring at 5.5 mab. Being characterized by alterations between warm/saltier and cold/fresher waters, only the most prominent $T / S$ changes that occurred during period from 29 January to 21 March 2008 (total 52 days) were selected and classified into four different types: fresh/cold (FC), saline/warm (SW) episodes, and transitional phases of intensive freshening/cooling and salinization/warming in between the relatively changeless FC and SW episodes. In order to emphasize periods of transition (and hence, $\mathrm{FC} / \mathrm{SW}$ episodes), the temperature and salinity at 5.5 mab were quantified as follows: 12-h running means of $T$ and $S$ were calculated. A start of transition period was defined as the portion of data where standard deviation of six sequential salinity measurements (equal to $1 \mathrm{~h}$ time interval) was at least 3 times larger than standard deviation of six previous measurements. According to Envisat images, the period of prominent $T / S$ changes (29 January-21 March 2008) fairly coincides with the opening of a coastal polynya in the central Laptev Sea in January-April 2008. However, several individual polynya events, indicated in Fig. 2 with gray bars, demonstrate no direct linkage between these events and the most remarkable $T / S$ transitions shown in Fig. 2.

The typical range of salinity during SW episodes ( $\# 3,7$ and 14) at 5.5 mab is between 31.8 and 32.1 psu which is $1.2-1.6$ psu saltier than the 30.5-30.6 psu that were recorded during FC episodes ( $\# 5,9$ and 12). The temperatures during $\operatorname{SW}\left(-1.15\right.$ to $\left.-1.30{ }^{\circ} \mathrm{C}\right)$ are $\sim 0.3-0.5^{\circ} \mathrm{C}$ warmer than during $\mathrm{FC}$ episodes $\left(-1.60\right.$ to $\left.-1.65^{\circ} \mathrm{C}\right)$. During $\mathrm{FC}$ episodes the temperatures are close to or slightly above freezing point that are characteristics for surface water during winter.

From 29 January to 21 March 2008 the CTD moored at 3 mab generally measured warmer $\left(-1.35\right.$ to $\left.-1.10{ }^{\circ} \mathrm{C}\right)$ and saltier $(31.6-$ 32.3) waters with a lower $T / S$ variability than at 5.5 mab. Although the 12-hour means of temperature and salinity at 3 mab and $5.5 \mathrm{mab}$ exhibit high correlations $(+0.76$ for temperature and +0.75 for salinity), the patterns of $T / S$ transitions and their amplitude are rather different. All FC episodes are characterized by maximum $T / S$ differences between 5.5 and 3 mab which indicates a stronger effect of freshening/cooling and salinization/ warming at 5.5 mab (Fig. 3).

Prior to 29 January the $T / S$ differences between 5.5 and 3.0 mab were rather small which points to a neutral density stratification within the warm bottom layer. The $T / S$ differences are also negligible from the end of April when temperatures were close to the freezing point as a consequence of ice-growing processes (Fig. 3).

Another pronounced feature of the temperature and salinity records at $5.5 \mathrm{mab}$ is periodic changes related to tidal motions. The predominant oscillation is associated with lunar semidiurnal $M_{2}$ tidal wave resulting in temperature and salinity fluctuations with mean amplitudes of $0.027{ }^{\circ} \mathrm{C}$ and $0.13 \mathrm{psu}\left(A_{T}\right.$ and $A_{S}$ respectively) during 29 January-21 March. These amplitudes are well above the $95 \%$ confidence level of $0.012{ }^{\circ} \mathrm{C}$ and $0.06 \mathrm{psu}$ while the lunar semidiurnal $T / S$ oscillations at 3 mab are not statistically confident.

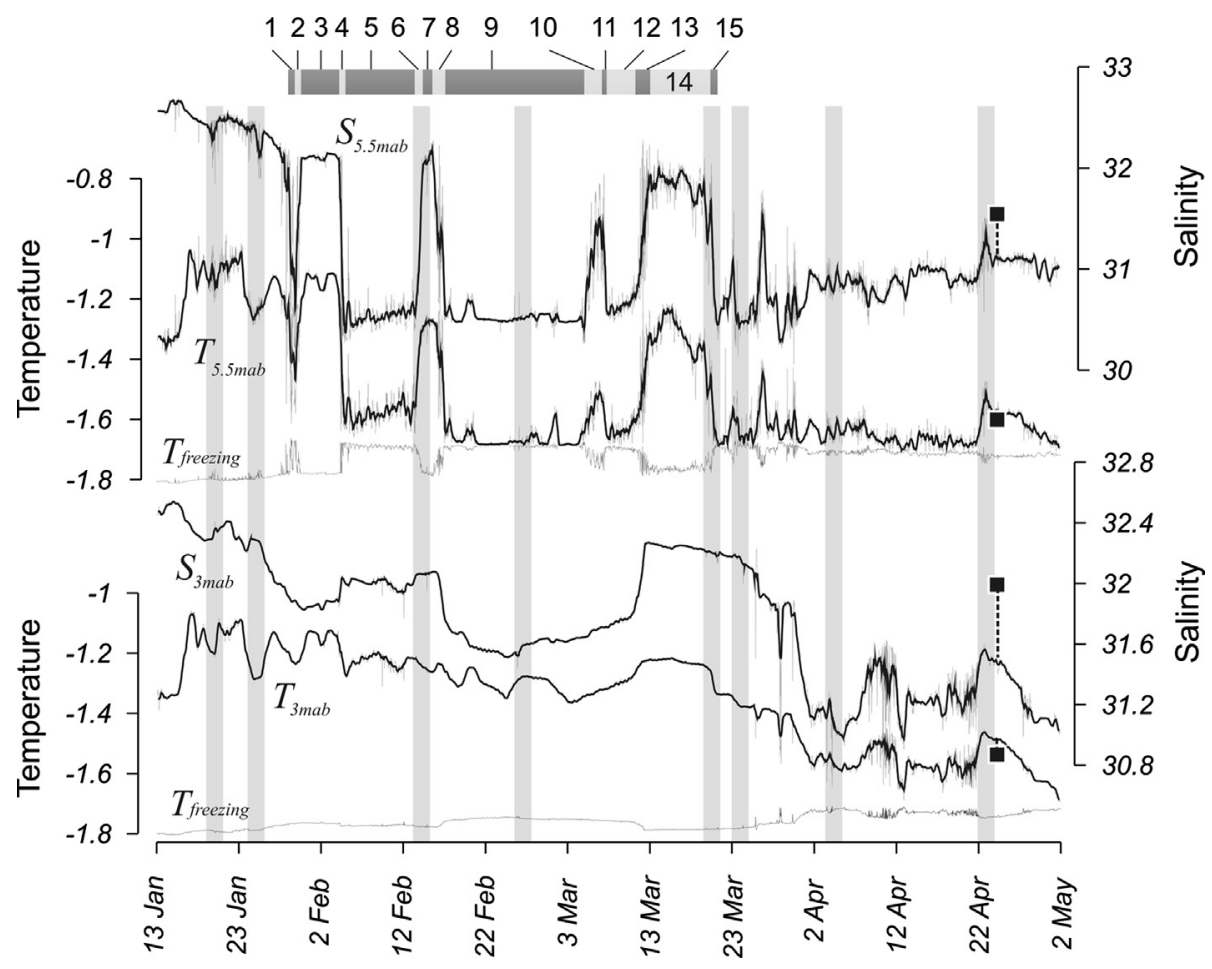

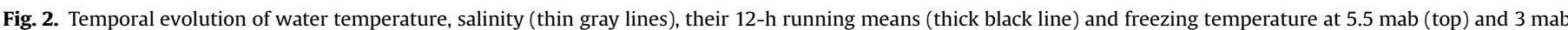

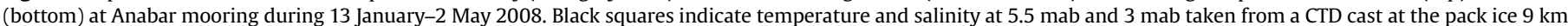

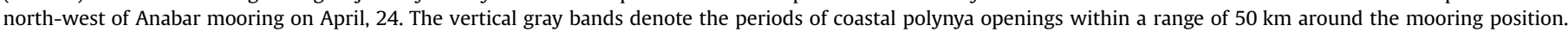

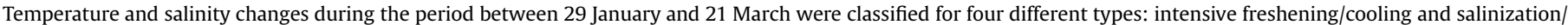
warming transitions, and relatively changeless fresh/cold (FC) and saline/warm (SW) episodes, marked with a numeric bar above (see details in the text). 


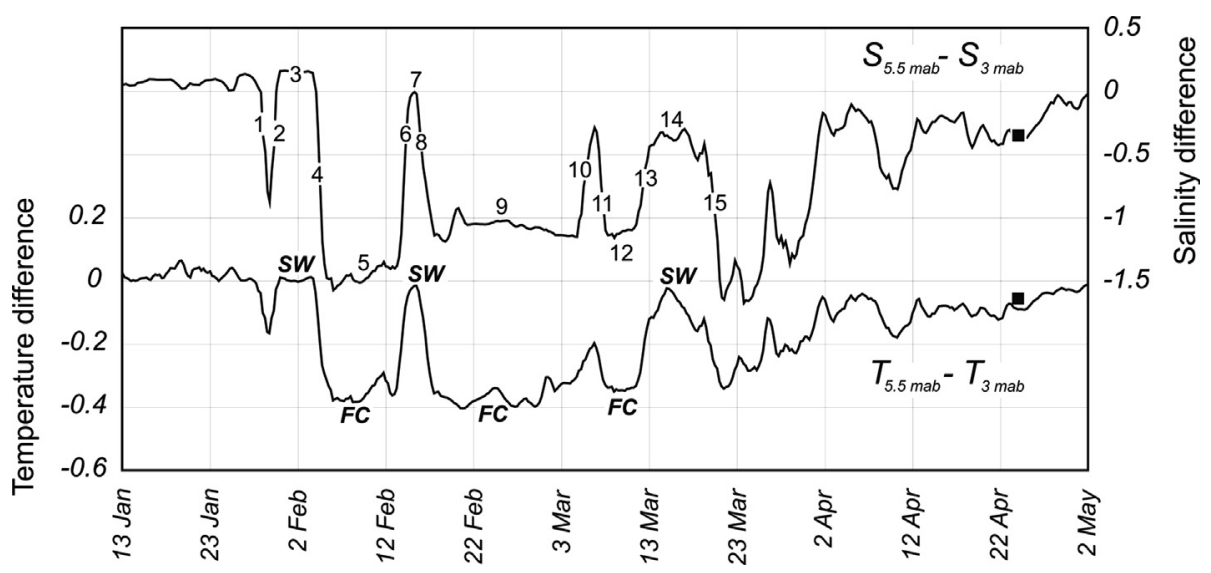

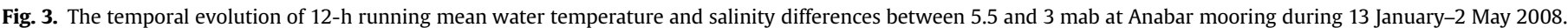
Black squares indicate the $T / S$ differences between 5.5 and 3 mab taken from a CTD cast at the pack ice 9 km north-west of Anabar mooring on 24 April.

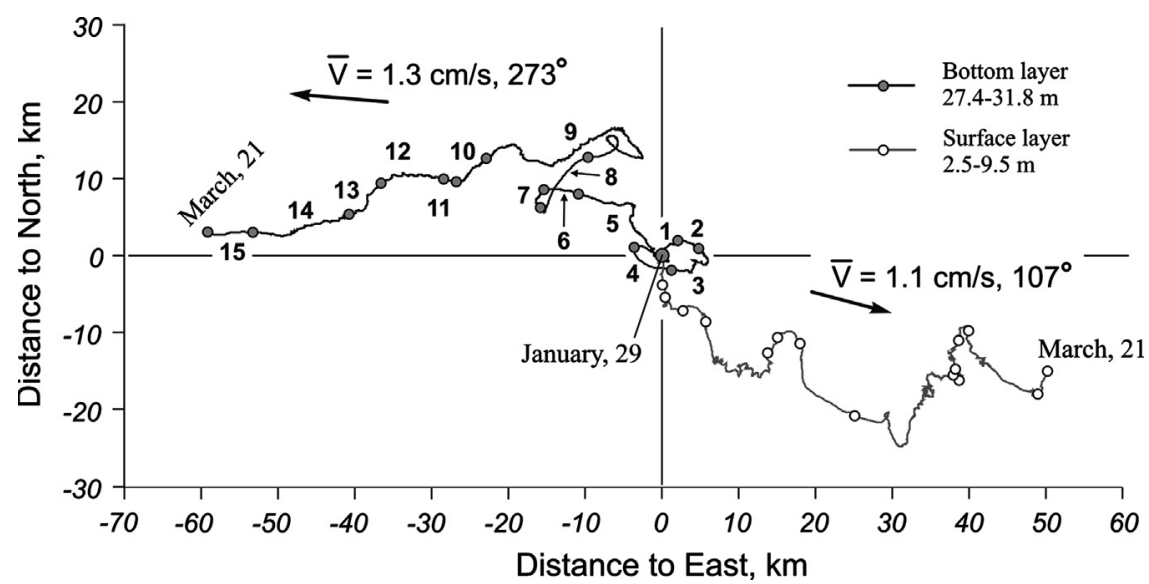

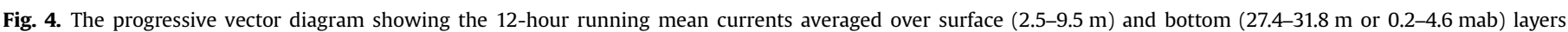

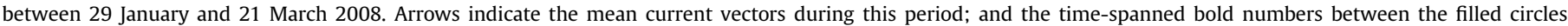
correspond to the numeric bar in Fig. 2.

\subsection{Current records}

The water dynamics at the Anabar mooring in February-March generally show a two-layer structure characterized by rather uniform mean current velocities within the surface $(0-10 \mathrm{~m})$ and bottom (less than $~ 10-12 \mathrm{mab}$ ) layers. South-westerly winds blowing along the polynya from the end of January until the end of May pushed surface waters with an average speed of $1.1 \mathrm{~cm} / \mathrm{s}$ to the east (Fig. 4). Due to the gap between reliable current records from $9.5 \mathrm{mab}$ (bin $\sharp 4$ at uplooking profiler) to $4.6 \mathrm{mab}$ (bin $\# 1$ at down-looking profiler) we only use data of the down-looking ADCP to characterize water dynamics near the seafloor. We found that from January 29 to March 21 the bottom waters mainly flew towards the west with an average speed of $1.3 \mathrm{~cm} / \mathrm{s}$ decreasing toward the seafloor due to the seabed friction. The observed two-layer water dynamics is in consistence with results of Dmitrenko et al. (2001a, 2001c) who reports the wind-driven currents in the surface layer and opposite compensatory currents within the bottom layer in the eastern Laptev Sea mid-shelf area.

All recorded currents demonstrate the semidiurnal oscillations attributed to the lunar semidiurnal tide. The tidal current ellipse is predominantly oriented south-to-north being in the range from $340^{\circ}$ to $20^{\circ}$ at $95 \%$ confidence level. The major and minor semiaxes of $M_{2}$ ellipse equal to 6.2 and $1.0 \mathrm{~cm} / \mathrm{s}$ respectively at 4.6 mab (as at the closest bin to the upper CTD sited at $5.5 \mathrm{mab}$ ). These values are $\sim 2$ times higher than $S_{2}$ tidal currents, while other tidal constituents are negligibly smaller.

\subsection{The horizontal thermohaline structure}

In Section 3.1, we showed that in January-April 2008 distinctive and abrupt thermohaline changes are evident during coastal polynya openings in the central Laptev Sea. The reversible character of these changes points more to horizontal advection as a cause for the variability than to vertical mixing. Therefore, to interpret the observed $T / S$ changeability referred to water dynamics the horizontal temperature and salinity gradients have to be additionally evaluated.

While no direct CTD measurements exist in the vicinity of the Anabar mooring, we can only estimate the local horizontal $T / S$ gradients by using the characteristics of the oscillatory tidal pattern of temperature and salinity at 5.5 mab. Fig. 5 represents the $M_{2}$ tidal ellipses derived from currents at 4.6 mab that are accompanied by corresponding $T / S$ variations at $5.5 \mathrm{mab}$ (the discrepancy of $0.9 \mathrm{~m}$ between the depth of currents and CTD measurements is believed to have a negligible effect on $T / S$ gradients estimation).

The $M_{2}$ tidal phases of temperature and salinity lag behind that of the currents by $\pi / 2$ or $90^{\circ}$ (see e.g., Nakajima and Hayakawa, 1982; Noble and Mullineaux, 1989). Taking into account this delay, the $T / S$ oscillatory pattern roughly corresponds to warm/salty waters advected from the north and cold/fresh waters from the south (Fig. 5). These directions are within 340-20 confidence range of $M_{2}$ tidal ellipse orientation and, hence, the horizontal $T / S$ 

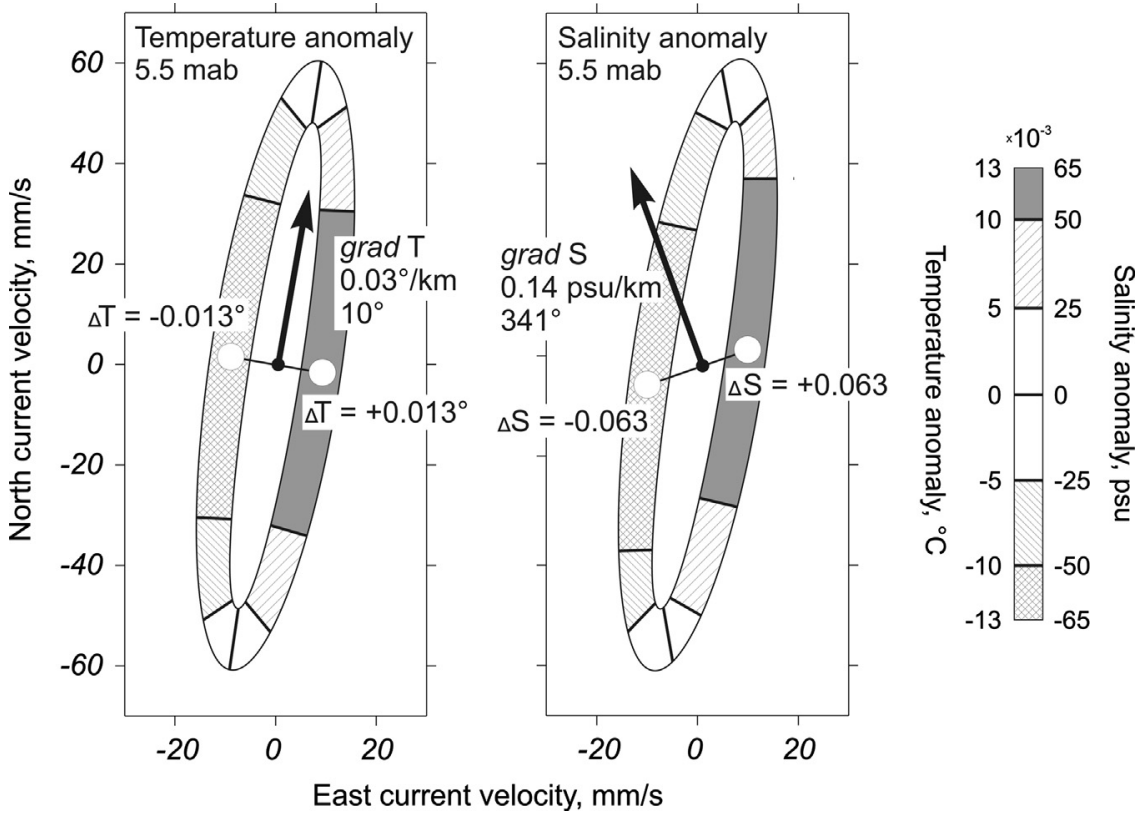

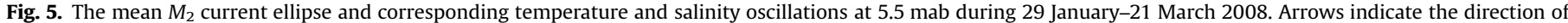
cross-frontal temperature and salinity gradients.

gradients at 5.5 mab can be estimated through the simple equations:

$T_{x}=\frac{\pi A_{T}}{A_{\text {major }} T_{M 2}}$, and $S_{x}=\frac{\pi A_{S}}{A_{\text {major }} T_{M 2}}$,

where $A_{\text {major }}$ is the semi-amplitude of current velocity along the major axis, and $T_{M 2}$ is the period of lunar semidiurnal cycle. Applying $A_{T}, A_{S}$ and $A_{\text {major }}$ estimated in Sections 3.1 and 3.2 yields to temperature and salinity gradients of about $0.3{ }^{\circ} \mathrm{C} / 10 \mathrm{~km}$ and $1.4 \mathrm{psu} / 10 \mathrm{~km}$.

To specify the horizontal TS-gradients at larger spatial scales we analyzed the mean de-tided current velocities at 4.6 mab during the rapid thermohaline transitions and the relatively changeless $\mathrm{FC} / \mathrm{SW}$ episodes. In general, the flow is directed to the north with an average speed of $5.5 \pm 1.5 \mathrm{~cm} / \mathrm{s}$ during freshening/cooling transition ( $\# 1,4,8,11$ and 15$)$ that is comparable with $3.4 \pm 0.5 \mathrm{~cm} / \mathrm{s}$ southward transport during salinization/warming transition ( $\# 2,6,10$ and 13 , Fig. 6). These currents are considerably faster than the mean current velocities observed during FC and SW episodes $(1.4 \pm 0.9 \mathrm{~cm} / \mathrm{s}$ and $1.8 \pm 0.9 \mathrm{~cm} / \mathrm{s}$ respectively). Note that our data set is too limited to hypothesize about the source of the observed short-term changes in water dynamics, thus a discussion of this phenomenon is beyond the scope of this paper.

The total distances that a parcel of water moves during each freshening/cooling or salinization/warming transition are presented in Fig. 6. Combined with corresponding $T / S$ changes at 5.5 mab these distances were used to quantify the local horizontal gradients of temperature and salinity. Considering south-to-north frontal zone orientation, we arbitrary choose transitions $\sharp 4,8,10$ and $\# 13$ which tentatively correspond to the cross-frontal motions. The inferred horizontal $T / S$ gradients, thus, should be considered as a lower bound. It was found that temperature gradients across the front at $5.5 \mathrm{mab}$ are in the range of $0.5-1.0^{\circ} \mathrm{C} / 10 \mathrm{~km}$ while gradients in salinity vary from 1.9 to $3.5 \mathrm{psu} / 10 \mathrm{~km}$. South-to-north orientations of temperature and salinity gradients are in consistence with those found from tidal analysis, though the scales of gradients are about 2-3 times larger.
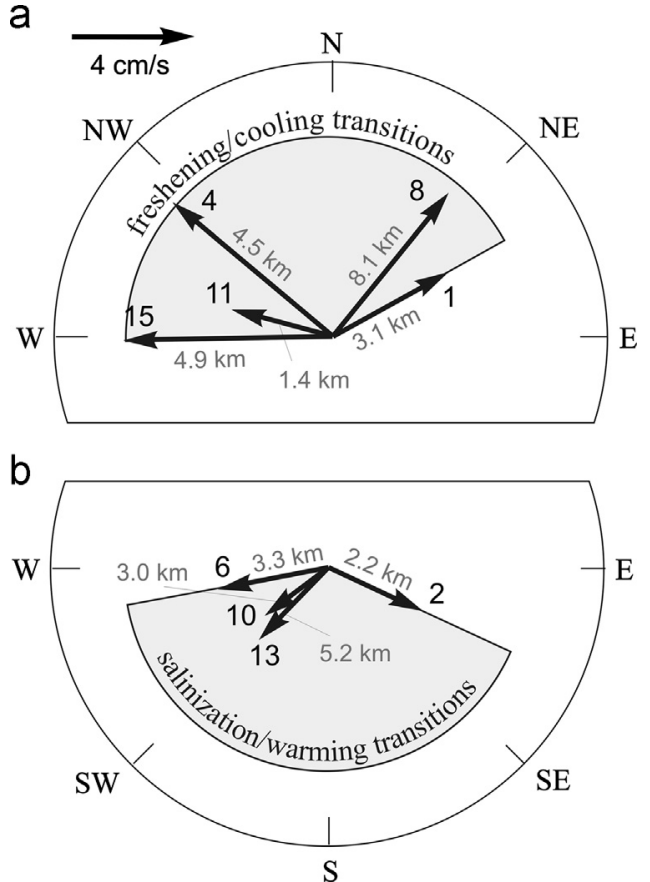

Fig. 6. Vector diagram of the de-tided mean currents velocities at 4.6 mab during (a) freshening/cooling transitions and (b) salinization/warming transitions at Anabar mooring during 29 January-21 March 2008. Gray numbers indicate the total shift of water parcel during each transition.

\section{Discussion}

Ice growth in polynya produces brine-enriched waters and increases the density at the surface. These denser waters could be further convectively mixed down resulting in salinification of entire water column above the density interface while the most intensive salinity increase is believed to occur near the seaward fast-ice edge (Krumpen et al., 2011). This basic concept is in contradiction with our findings showing fresher waters toward fast-ice edge of polynya. But what is the origin of these fresher 
waters in the lower part of the water column in polynya resulting in positively correlated temperature/salinity anomalies induced by lateral advection?

To reveal the source of observed thermohaline changes we first address Dmitrenko et al. (2010a) who examined two-week mooring records at the WNS polynya fast-ice edge in April-May 2008. The positively correlated bottom temperatures and salinities in those records were attributed to recurrent wind-driven warm and salty intrusions of Atlantic-modified low-halocline water from the outer shelf. These intrusions measured at $\sim 1$ mab were about 1.0 -1.5 psu saltier and only $0.05-0.08{ }^{\circ} \mathrm{C}$ warmer in comparison with initial water characteristics before the intrusive inflow (Dmitrenko et al., 2010a, Fig. 10). The mechanism of AW intrusion near the bottom intends that warmer and saltier waters replace the local cold and relatively less saline waters. Assuming the AW intrusive origin, we expect that the most intensive $T / S$ anomalies should be found near the bottom and lower values closer to the surface. In contrast, the 12-h mean $T / S$ time series showed about two times higher thermohaline fluctuations at $5.5 \mathrm{mab}$ than at $3 \mathrm{mab}$ in February-March, 2008.

Another factor discarding the AW nature of the observed $T / S$ changes relates to the paper of Hoelemann et al. (2011) who reported the extraordinary warming of the bottom waters in the central Laptev Sea in September 2007. This thermal anomaly associated with solar heating and vertical mixing due to the autumn storms was further traced until April 2008 (Hoelemann et al., 2011). The mean temperature difference between 5.5 and 3 mab at Anabar mooring was well above zero (on average $+0.19{ }^{\circ} \mathrm{C}$ with higher temperatures at $5.5 \mathrm{mab}$, not shown) from September, 21 until the first freshening/cooling transition in January, 29 when temperature at 5.5 mab became lower than at 3 mab. This fact clearly implies that warm bottom waters were modified here by sporadic invasion of cold waters since the end of January.

The horizontal temperature and salinity gradients, varying from 0.3 to $1.0{ }^{\circ} \mathrm{C} / 10 \mathrm{~km}$ and from 1.4 to $3.5 \mathrm{psu} / 10 \mathrm{~km}$, respectively, were evaluated by using two different approaches. Both methods give values an order of magnitude higher than 0.010$0.015{ }^{\circ} \mathrm{C} / 10 \mathrm{~km}$ and $0.2-0.4 \mathrm{psu} / 10 \mathrm{~km}$ calculated from historical $\mathrm{T} /$ $S$ records in the bottom layer in the WNS polynya area (Dmitrenko et al., 2010a). Krumpen et al. (2011) using the bulk estimations reported the salinity gradients of about $2.5-5.5 \mathrm{psu} / 10 \mathrm{~km}$ formed by salt rejection estimated from the sea-ice growing polynya model at the surface of WNS polynya near the fast-ice edge. Beside the decline of these gradients with both depth and distance from the fast-ice edge, salinity decreases off the fast-ice edge is in opposition with our finding of less saline waters southward of the mooring.

Based on all these findings, we propose that the abrupt thermohaline transitions cannot be attributed to the lateral mixing or advection neither in the surface nor in the bottom mixed layers. Thus, we assume that the observed $T / S$ changes result from the altering pycnocline depths across the polynya and sporadic transition of density interface across the CTD loggers. It implies that horizontal motions through the locally reinforced (by altering pycnocline depth) horizontal gradients bring water with temperatures and salinities associated with different parts of water column: (1) from the surface mixed layer with temperatures close to freezing point and (2) from the warmer/saltier bottom waters. The results presented in Section 3.3 suggest that salinities at 5.5 mab decrease towards the south intending deeper pycnocline and, hence, thicker surface mixed layer toward the fast-ice edge of polynya.

Most likely the negative salinity anomaly in the pycnocline layer would have resulted from penetrative convection or mixing through the density interface that entrains relatively fresher surface waters to the deeper layers. The general principle of this mechanism consists in that the convective cells of cold salty waters acquire enough kinetic energy to overshoot the base of the mixed layer, working against gravity and mixing the fluid at the density interface (Soloviev and Klinger, 2001). The strong vertical stratification could considerably eliminate penetrative convection that particularly concerns the eastern Laptev Sea where Lena River supplies $\sim 525 \mathrm{~km}^{3}$ freshwater per year (Lammers et al., 2001). Nevertheless, the mean climatic salinity profiles in the mooring position indicate the recurring summer-to-winter salinity decreases near the bottom (not shown). Since there is no other source of freshwater during winter this implies that density interface is not impenetrable for vertical mixing between relatively fresher surface and more saline bottom waters resulting in lower (0.2-0.5 psu) salinities in the depth range of 23-32 $\mathrm{m}$ during winter.

The measurements at few stations in the central Laptev Sea polynya can be also referred here to support the idea of penetrative mixing in pycnocline. The snapshot winter oceanographic surveys carried out in May 1996 and April 2008 showed variations of surface mixed layer thickness across the polynya. As a result of observed variations, the distinct horizontal $T / S$ gradients are evident at the intermediate depths marked with gray bars in Fig. 7. Fresher and colder water of surface mixed layer contrast with saltier and warmer waters below the pycnocline at these specific depth intervals. It further implies that any lateral motions here lead to positively correlated changes in temperature and salinity similar to those captured at Anabar mooring.

In general, two categories of physical processes could result in thicker surface mixed layer and freshening of pycnocline layer in polynya: the penetrative gravity convection and/or penetrative mixing induced by mechanical forcing by different sources. All the mechanisms which are able to mix fresher waters from the surface layer down to the deeper interior are listed in the following sections.

\subsection{Penetrative gravity convection}

Studying the penetrative convection in polynyas is difficult due to the scarcity of CTD measurements, although some observational (Melling et al., 2001; Bacle et al., 2002) and numerically simulated (e.g. Julien et al., 1996; Buffoni et al., 2002) examples of convective entrainment are known. For instance, similar to our findings, Melling (2001) reported abrupt decreases in salinity accompanied with drops in temperature to the freezing point, attributing them to the penetrative convection within the North Water polynya. The intensity of penetrative convection strongly depends on the buoyancy flux at the surface and the vertical gradient of density beneath the surface mixed layer (Melling et al., 2001). However, a rough estimation of the entrainment extent can be done by applying an empirical approximation, presuming that the positive buoyancy entrainment flux in the pycnocline is expected to be a constant fraction of the negative buoyancy flux at the sea surface (Ball, 1960). Based on observations and simulations, this fraction is roughly estimated to be -0.2 (Caughey, 1982; Moeng and Wyngaard, 1984).

Following Yeager and Large (2007), we can roughly quantify the fraction of positive buoyancy flux from below by considering the vertical stratifications observed in polynya and under the fast ice edge in May 1996 and April 2008 (Fig. 7). Stations Ln96-19 and Ti08-20 are assumed to present the undisturbed (or initial) vertical stratification while stratification at stations Ln96-22 and Ti08-16 shows the result of convective mixing due to ice growing and brine release in polynya.

The net heat flux in polynya results in negative buoyancy flux at the surface which is attributed to salt rejection due to the ice formation, while effect of water temperature decrease is negligible in terms of density changes. Salinity profiles were used to estimate 

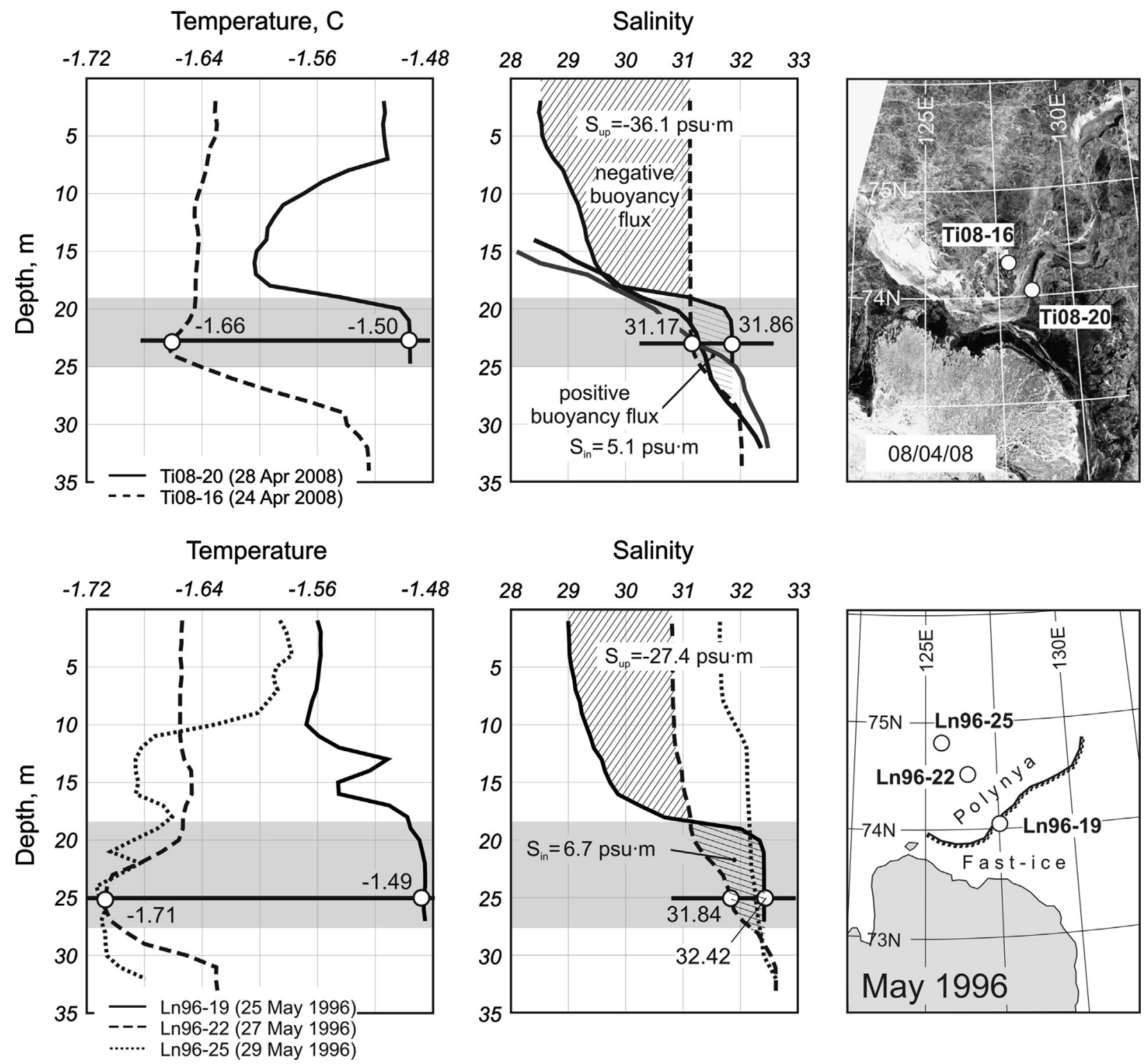

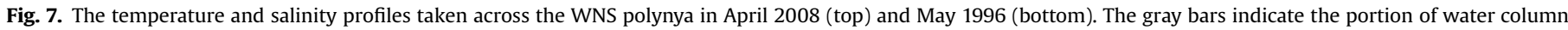
where warmer/saltier waters contrast with colder/fresher waters within pycnocline.

the ratio of buoyancy changes above (loss) and below (gain) the entrainment depth ( $\sim 19 \mathrm{~m}$ for both examples) which is proportional to the ratio between cumulative salinity changes in the intermediate $\left(S_{i n}\right)$ and surface $\left(S_{u p}\right)$ layers (see Fig. 7). Chosen salinity profiles yield to $S_{i n} / S_{u p}$ equal to -0.24 and -0.14 (in 1996 and 2008, respectively) or to the same order of magnitude as reported by Caughey (1982) and Moeng and Wyngaard (1984), confirming that the effect of entrainment is possible from the energetic point of view. However, these values are very rough since chosen stations are distant and do not present the temporal evolution of the same salinity profile. Thus, the observed salinity differences are related not only to ice growth but also to the changes of salinity across the frontal zone formed by the Lena River runoff.

\subsection{Shear-driven and other mechanical mixing}

The enhanced mixing within pycnocline in the polynya area might be a result of the impact of different mechanical factors besides the penetrative gravity convection.
First, the wind forcing over the open polynya may develop the Langmuir circulation cells which play a significant role in upperocean dynamics and deepen the surface mixed layer by entraining waters from beneath (Li and Garrett, 1997; Kukulka et al., 2010). The combination of Langmuir circulation and shear-driven instabilities work intimately together to deepen the mixed layer (Kukulka et al., 2010). For the WNS polynya area, the long linear streaks of frazil ice attributed to the Langmuir circulation were observed in April 2008 (Dmitrenko et al., 2010b). Nevertheless, polynya openings in February-March accompanied by low air temperatures reinforce formation of new ice which, in turn, suppresses the wind-forced mixing processes.

The second potential source of enhanced vertical mixing trough pycnocline in polynya originates from the shear instability conditioned by the two-layer vertical structure of wind-driven dynamics (Dmitrenko et al., 2001a, 2005). In Section 3.2 we indicated that the observed water dynamics infer the shear across the density interface separating eastward surface flow and nearbottom westward current. Another source of shear instability at intermediate depths is connected to the baroclinic mode of 

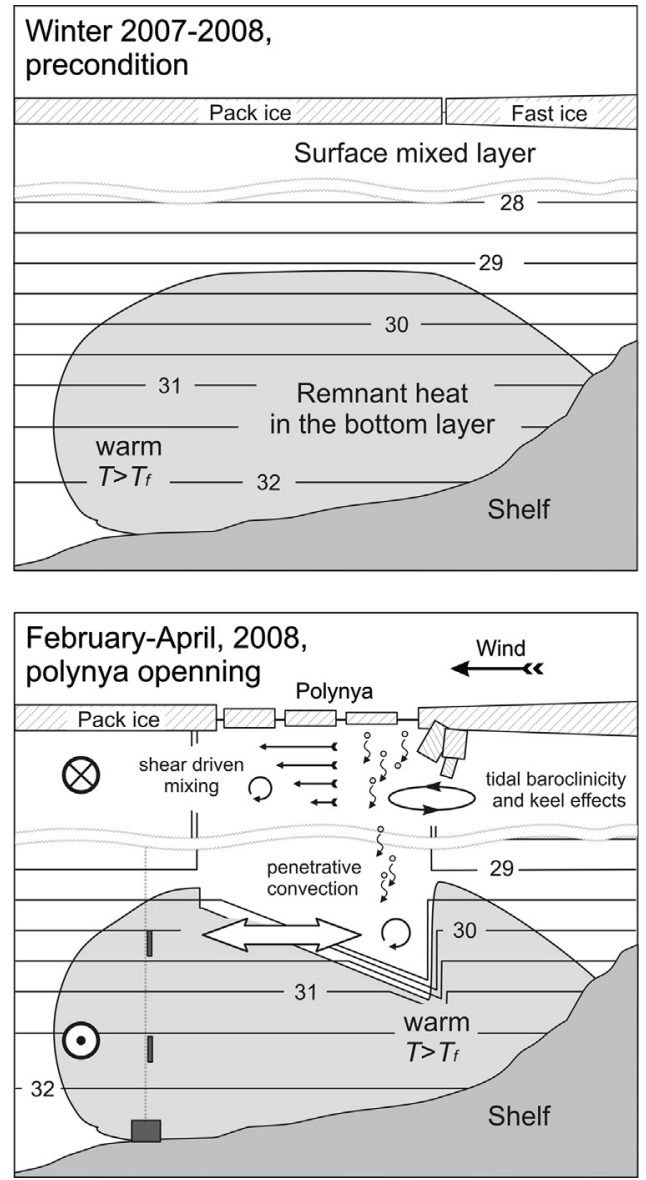

Fig. 8. The schematic overview of penetrative mixing trough pycnocline within wind-driven polynya area.

internal tidal motions in the area under study (Dmitrenko et al., 2005,2012 ). The shear-driven instability of both, the mean flow and tidal oscillations can result in entrainment at density interface depending upon the local Richardson number. Dmitrenko et al. (2012) reported that small Richardson numbers observed at the fast-ice edge indicate the possibility of turbulence and vertical mixing in pycnocline.

The vertical mixing due to ice keels is another stirring mechanism that may strongly affect the surface mixed layer depth (Shirasawa and Ingram, 1997; Skyllingstad and Dendo, 2001; Skyllingstad et al., 2003). Because of the shiftable character of pack ice movement, the seaward fast ice edge is often heavily ridged in comparison with adjacent ice with inclusion of bottomanchored stamukhi (Macdonald et al., 1995). These ridges form obstacles which considerably increase the parameter of roughness length in the surface boundary layer (Shaw et al., 2008). Combined with reversible tidal currents across the fast-ice edge (Dmitrenko et al., 2010b), ice keels can produce strong turbulent mixing even in a shear-free stable density interface (McGrath et al., 1997a, 1997b).

All mentioned factors may potentially affect the pycnocline depth in the WNS coastal polynya area entraining fresher surface waters into the stratified interior below. Fig. 8 schematically represents the penetrative mixing in the context of oceanographic observations carried out at Anabar mooring station in February-March, 2008. Though the commonly accepted concept of entrainment within the density interface of polynya is not developed, this figure illustrates the scope of driving mechanisms.

\section{Conclusions}

Our paper focuses on the events of positively correlated temperature and salinity changes in pycnocline measured at the year-long mooring station within the area of WNS coastal polynya since 29 January and until the end of March, 2008. According to the generally accepted knowledge, polynya produces the brineenriched waters with temperatures close to the freezing point due to ice growth. This basic concept is in contraposition with our observations showing advection of colder and fresher waters in the polynya region.

Since the local ice-related processes being acting alone cannot produce the observed recurrent thermohaline changes, the alternative hypothesis about advective origin of these changes was put forward. We test the velocity records to identify the favorable direction where do the cold and fresh waters, modifying the local temperature and salinity at the depth of density interface, come from. It was revealed that periods with fresher waters at the freezing point coincide with northward currents, while southward currents bring salty and warm waters to the position of the mooring. The horizontal gradients of temperature and salinity at $5.5 \mathrm{mab}$ level were found to reach $0.3-1.0^{\circ} \mathrm{C} / 10 \mathrm{~km}$ and of 1.4 $3.5 \mathrm{psu} / 10 \mathrm{~km}$, respectively, that is well above the expected gradients in the surface or bottom layers out of the density interface. We hypothesize that observed gradients are formed by the altering pycnocline depths across the polynya and deeper surface mixed layer thickness toward the fast-ice edge. The negative salinity anomalies in the lower part of the surface mixed layer (specified by temperatures near the freezing point) in this case are expected to be advected from the fast-ice edge of polynya.

We further suggest that the penetrative mixing is the only plausible source of fresher signal within the lower part of mixed layer. Driven by different physical processes, this mixing results in fresher surface water entrainment into the stratified waters beneath. While it is not known which mechanism impacts the rate of entrainment, we suggest several processes which could be responsible for the mixing. Gravity convection due to intensive ice growth is one of them. Another source of entrainment in pycnocline is the shear-driven mixing originated from two-layer water dynamics and/or baroclinic tidal motions. The heavily ridged seaward fast-ice edge can also result in strong turbulent mixing even in a shear-free density interface due to the increased roughness at the lower surface of sea-ice.

While we focus on the Laptev Sea shelf area, the processes are believed to be relevant to other polynyas on Arctic shelves. This should improve our understanding of the physical processes determining the vertical thermohaline structure in polynyas on the Arctic shelves during winter. The results of our study might be also important for considering the transparency of density interface in terms of vertical heat and salt fluxes in polynya interior. Future studying of the penetrative mixing in the WNS polynya should be based on mooring measurements carried out by autonomous profiling system taking CTD casts on a roughly hourly basis and accompanied by regular current velocity measurements across the polynya.

\section{Acknowledgments}

This research was funded by the German ministry BMBF (OSL grant 09-11). Another financial support through the BMBF project "System Laptev Sea-The Eurasian Shelf Seas in the Arctic's Changing Environment: Frontal Zones and Polynya Systems in the Laptev Sea" is gratefully acknowledged. We wish also to thank T. Klagge (GEOMAR) for his assistance with mooring deployment and recovering. 


\section{References}

Aagaard, K., Coachman, L.K., Carmack, E.C., 1981. On the halocline of the Arctic Ocean. Deep Sea Research 28, 529-545.

Bacle, J., Carmack, E.C., Ingram, R.G., 2002. Water column structure and circulation under the North Water during spring transition: April-July 1998. Deep-Sea Research (II) 49, 4907-4925.

Ball, F.K., 1960. Control of inversion height by surface heating. Quarterly Journal of the Royal Meteorological Society 86, 483-494.

Bareiss, J., Görgen, K., 2005. Spatial and temporal variability of sea ice in the Laptev Sea: analyses and review of satellite passive microwave data and model results, 1979 to 2002. Global and Planetary Change 48 (1-3), 28-54.

Buffoni, G., Cappelletti, A., Picco, P., 2002. An investigation of thermohaline circulation in Terra Nova Bay polynya. Antarctic Science 14 (I), 83-92.

Caughey, S.J., 1982. Observed characteristics of the atmospheric boundary layer. In: Nieuwstadt, F.T.M., van Dop, H. (Eds.), Atmospheric Turbulence and Air Pollution Modelling. Reidel, pp. 107-158.

Cavalieri, D.J., Martin, S., 1994. The contribution of Alaskan, Siberian, and Canadian coastal polynyas to the halocline layer of Arctic Ocean. Journal of Geophysical Research 99 (C9), 18343-18362.

Dethleff, D., Loewe, P., Kline, E., 1998. Detailed investigation on ice formation and export during 1991/1992 winter season. Cold Region Science and Technology 27, 225-243.

Dmitrenko, I., Hoelemann, J., Kirillov, S., Berezovskaya, S., Eicken, H., Kassens, H., 2001a. Wind-forced currents as a linkage between the Laptev Sea (Siberia) and the Arctic Ocean. In: Proceedings of the American Meteorological Society 11 th Conference on Interaction of the Sea and Atmosphere and Sixth Conference on Polar Meteorology and Oceanography, at San Diego, California, USA, 14-18 May 2001.

Dmitrenko, I., Tyshko, K., Kirillov, S., Hölemann, J., Eicken, H., Kassens, H., 2005. Impact of flaw polynyas on the hydrography of the Laptev Sea. Global and Planetary Change 48, 9-27.

Dmitrenko, I.A., Hölemann, J.A., Kirillov, S.A., Wegner, C., Gribanov, V.A., Berezovskaya, S.L., Kassens, H., 2001b. Thermal regime of the Laptev Sea bottom layer and affecting processes. Earth Cryosphere 5 (3), 40-55 (in Russian).

Dmitrenko, I.A., Hoelemann, J.A., Kirillov, S.A., Berezovskaya, S.L., Kassens, H., 2001c. Role of barotropic sea level changes in current formation on the eastern shelf of the Laptev Sea. Doklady Earth Science 377 (2), 243-249.

Dmitrenko, I.A., Kirillov, S.A., Tremblay, B., Bauch, D., Willmes, S., 2009. Sea-ice production over the Laptev Sea shelf inferred from historical summer-to winter hydrographic observations of 1960s-1990s. Geophysical Research Letters 36, L13605, http://dx.doi.org/10.1029/2009GL038775.

Dmitrenko, I.A., Kirillov, S.A., Tremblay, L.B., Bauch, D., Hölemann, J.A., Krumpen, T., Kassens, H., Wegner, C., Heinemann, G., Schröder, D., 2010a. The Arctic Ocean Atlantic water layer impacts the Siberian shelf hydrography. Journal of Geophysical Research 115, C08010, http://dx.doi.org/10.1029/2009JC006020.

Dmitrenko, I.A., Wegner, C., Kassens, H., Kirillov, S.A., Krumpen, T., Heinemann, G., Helbig, A., Schroder, D., Holemann, J.A., Klagge, T., Tyshko, K.P., Busche, T., 2010b. Observations of supercooling and frazil ice formation in the Laptev Sea coastal polynya. Journal of Geophysical Research 115, C05015, http://dx.doi.org/ 10.1029/2009JC005798.

Dmitrenko, I.A., Kirillov, S.A., Bloshkina, E., Lenn, Y., 2012. Tide-induced vertical mixing in the Laptev Sea coastal polynya. Journal of Geophysical Research 117, C00G14, http://dx.doi.org/10.1029/2011JC006966 19 pp..

Fofonoff, P., Millard Jr., R.C., 1983. Algorithms for computation of fundamental properties of seawater. UNESCO Technical Papers in Marine Science 44, 53.

Foreman, M.G.G., 1977. Manual for Tidal Heights Analysis and Prediction Pacific Marine Science Report 77-10. Institute of Ocean Sciences, Patricia Bay, Sidney, BC 97 pp.

Foreman, M.G.G., 1978. Manual for Tidal Currents Analysis and Prediction Pacific Marine Science Report 78-6. Institute of Ocean Sciences, Patricia Bay, Sidney, BC $57 \mathrm{pp}$.

Hoelemann, J.A., Kirillov, S., Klagge, T., Novikhin, A., Kassens, H., Timokhov, L., 2011. Near-bottom water warming in the Laptev Sea in response to atmospheric and sea-ice conditions in 2007. Polar Research30, http://dx.doi.org/10.3402/polar. v30i0.6425.

Julien, K., Legg, S., McWilliams, J., Werne, J., 1996. Penetrative convection in rapidly rotating flows: preliminary results from numerical simulation. Dynamics of Atmospheres and Oceans 24, 237-249.
Krumpen, T., Hölemann, J.A., Willmes, S., Morales Maqueda, M.A., Busche, T., Dmitrenko, I.A., Gerdes, R., Haas, C., Heinemann, G., Hendricks, S., Kassens, H., Rabenstein, L., Schröder, D., 2011. Sea ice production and water mass modification in the eastern Laptev Sea. Journal of Geophysical Research 116, C05014, http://dx.doi.org/10.1029/2010JC006545.

Kukulka, T., Plueddemann, A., Trowbridge, J.H., Sullivan, P.P., 2010. Rapid mixed laye deepening by the combination of Langmuir and shear instabilities: a case study. Journal of Physical Oceanography , http://dx.doi.org/10.1175/2010JPO4403.1.

Lammers, R.B., Shiklomanov, A.I., Vörösmarty, C.J., Fekete, B.M., Peterson, B.J., 2001 Assessment of contemporary Arctic river runoff based on observational discharge records. Journal of Geophysical Research-Atmospheres 106 (D4) 3321-3334.

Li, M., Garrett, C., 1997. Mixed layer deepening due to Langmuir circulation. Journal of Physical Oceanography 27, 121-132.

Macdonald, R.W., Paton, D.W., Carmack, E.C., Omstedt, A., 1995. The freshwate budget and under-ice spreading of Mackenzie River water in the Canadian Beaufort Sea based on salinity and $\mathrm{O}_{18} / \mathrm{O}_{16}$ measurements in water. Journal of Geophysical Research 100, 895-919.

Martin, S., Cavalieri, D.J., 1989. Contribution of the Siberian shelf polynyas to the Arctic Ocean intermediate and deep water. Journal of Geophysical Research 94 (C9), 12,725-12,738

McGrath, J.L., Fernando, H.J.S., Hunt, J.C.R., 1997a. Turbulence, waves and mixing at shear-free density interfaces. Part 1. A theoretical model. Journal of Fluid Mechanics 347, 197-234.

McGrath, J.L., Fernando, H.J.S., Hunt, J.C.R., 1997b. Turbulence, waves and mixing at shear-free density interfaces. Part 2. Laboratory experiments. Journal of Fluid Mechanics 347, 235-261.

Melling, H., Gratton, Y., Ingram, G., 2001. Ocean circulation within the North Water polynya of Baffin Bay. Atmosphere-Ocean 39 (3), 301-325.

Moeng, C.-H., Wyngaard, J.C., 1984. Statistics of conservative scalars in the convective boundary layer. Journal of Atmospheric Sciences 41, 3161-3169.

Nakajima, H., Hayakawa, N., 1982. A cross-correlation analysis of tidal current water temperature and salinity records. Journal of the Oceanographical Society of Japan 38, 52-56.

Noble, I., Mullineaux, L.S., 1989. Internal tidal currents over the summit of Cross Seamount. Deep-Sea Research 36, 1791-1802.

Pawlowicz, R., Beardsley, B., Lentz, S., 2002. Classical tidal harmonic analysis including error estimates in MATLAB using T_TIDE. Computers and Geosciences 28, 929-937.

Shaw, W.J., Stanton, T.P., McPhee, M.G., Kikuchi, T., 2008. Estimates of surface roughness length in heterogeneous under-ice boundary layers. Journal of Geophysical Research 113, C08030, http://dx.doi.org/10.1029/2007JC004550.

Shirasawa, K., Ingram, R.G., 1997. Currents and turbulent fluxes under the first-year ice in Resolute Passage, Northwest Territories, Canada. Journal of Marine System 11, 21-32.

Skyllingstad, E.D., Dendo, D.W., 2001. Turbulence beneath sea ice and leads: a coupled sea ice/large-eddy simulation study. Journal of Geophysical Research 106 (C2), 2477-2497.

Skyllingstad, E.D., Paulson, C.A., Pegau, S., McPhee, M.G., Stanton, T., 2003. Effects of keels on ice bottom turbulence exchange. Journal of Geophysical Research 108, C12, http://dx.doi.org/10.1029/2002JC001488.

Soloviev, A., Klinger, B., 2001. Open Ocean Convection. In: Steele, J.H., Thorpe, S.A Turekian, K.K. (Eds.), Encyclopedia of Ocean Sciences, vol. I. Academic Press, London, pp. 2015-2022.

Willmes, S., Adams, S., Schroeder, D., Heinemann, G., 2011. Spatio-tempora variability of polynya dynamics and ice production in the Laptev Sea between the winters of $1979 / 80$ and $2007 / 08$. Polar Research 30, 5971, http://dx.doi.org 10.3402/polar.v30i0.5971.

Winsor, P., Bjork, G., 2000. Polynya activity in the Arctic Ocean from 1958 to 1997 Journal of Geophysical Research 105 (C4), 8789-8803.

Yeager, S.G., Large, W.G., 2007. Observational evidence of winter spice injection. Journal of Physical Oceanography. 37, 2895-2919, http://dx.doi.org/10.1175 2007JPO3629.1

Zakharov, V.F., 1966. Rol' zapripaynih poliney v gidrologichskom I ledovom rejime moray Laptevih (The role of trans-fast ice polynyas in hydrological regime of the Laptev Sea). Okeanologiia 6 (6), 1014-1022 (in Russian). 